\title{
Improved estimates of glacier change rates at Nevado Coropuna Ice Cap, Peru
}

\author{
WILLIAM H. KOCHTITZKY, ${ }^{1,2,3}$ BENJAMIN R. EDWARDS, ${ }^{3}$ ELLYN M. ENDERLIN, ${ }^{1,2}$ \\ JERSY MARINO, ${ }^{4}$ NELIDA MARINQUE ${ }^{4}$
}

${ }^{1}$ School of Earth and Climate Sciences, University of Maine, Orono, ME, USA

${ }^{2}$ Climate Change Institute, University of Maine, Orono, ME, USA

${ }^{3}$ Department of Earth Sciences, Dickinson College, Carlisle, PA, USA

${ }^{4}$ Observatorio Vulcanológico del INGEMMET, Arequipa, Perú

Correspondence: William Kochtitzky <william.kochtitzky@maine.edu>

\begin{abstract}
Accurate quantification of rates of glacier mass loss is critical for managing water resources and for assessing hazards at ice-clad volcanoes, especially in arid regions like southern Peru. In these regions, glacier and snow melt are crucial dry season water resources. In order to verify previously reported rates of ice area decline at Nevado Coropuna in Peru, which are anomalously rapid for tropical glaciers, we measured changes in ice cap area using 259 Landsat images acquired from 1980 to 2014. We find that Coropuna Ice Cap is presently the most extensive ice mass in the tropics, with an area of $44.1 \mathrm{~km}^{2}$, and has been shrinking at an average area loss rate of $0.409 \mathrm{~km}^{2} \mathrm{a}^{-1}\left(\sim 0.71 \% \mathrm{a}^{-1}\right)$ since 1980. Our estimated rate of change is considerably lower than previous studies $\left(1.4 \mathrm{~km}^{2} \mathrm{a}^{-1}\right.$ or $\left.\sim 2.43 \% \mathrm{a}^{-1}\right)$, but is consistent with other tropical regions, such as the Cordillera Blanca located $\sim 850 \mathrm{~km}$ to the NW $\left(\sim 0.68 \% \mathrm{a}^{-1}\right)$. Thus, if glacier recession continues at its present rate, our results suggest that Coropuna Ice Cap will likely continue to contribute to water supply for agricultural and domestic uses until $\sim 2120$, which is nearly 100 years longer than previously predicted.
\end{abstract}

KEYWORDS: glacier monitoring, mountain glaciers, remote sensing, tropical glaciology, volcanoes/ice and snow interactions

\section{INTRODUCTION}

Although waxing and waning of terrestrial ice has been the hallmark of Earth's climate system since at least the Pleistocene, recent evidence that almost all terrestrial ice bodies are presently losing mass is a concerning sign of anthropogenic climate change (Kargel, 2014). Rates of mass loss are particularly concerning in the tropics (Kaser, 1999), where changes in glacier meltwater fluxes pose serious risks to downstream communities. Peru is home to $70 \%$ of Earth's tropical glaciers and meltwater from Peruvian glaciers provides a critical water source for domestic consumption, hydropower generation and agriculture, especially during dry seasons (Vuille and others, 2008). As urban centers grow in the Andes, water resources are being increasingly strained by rising demand for water (Magrin and others, 2014). These compounding factors make the people of Peru particularly vulnerable to long-term water shortages associated with glacier loss.

Changes in volcanic activity can also lead to rapid changes in glacier volume that pose a serious short-term hazard to local communities (Major and Newhall, 1989; Pierson, 1995; Delgado-Granados and others, 2015; Smellie and Edwards, 2016). The 1985 eruption and ensuing volcanic mudflow at Nevado del Ruiz, which killed over 23000 Colombians, is an iconic example (Pierson, 1995). Even without an eruption, volcanic heat fluxes can cause increased melting and jökulhlaups through ice melting during magma recharge events (Björnsson, 1988). While these types of events are rare, quantifying upstream ice extent is important for the assessment and mitigation of potential downstream hazards.
Here we focus on El Nevado Coropuna $\left(15^{\circ} 33^{\prime} \mathrm{S}, 72^{\circ} 38^{\prime} \mathrm{W}\right.$, 6425 m.a.s.l.) in southern Peru, which is a glacierized volcanic complex with an areal ice cap extent of $44.1 \mathrm{~km}^{2}$ (in 2014; Fig. 1). We focus on Coropuna Ice Cap for several reasons. First, Coropuna represents the largest fresh water reserve for the region of Arequipa, which relies on snow and ice melt to support its population of 1.15 million people (INEI, 2007; Úbeda, 2011; Silverio and Jaquet, 2012). Second, an eruption from Coropuna has the potential to produce lahars that could affect populations in the Condesuyos, Castilla and Camaná provinces. According to the 2007 Peruvian Census, 57416 people live in the Condesuyos and Castilla provinces spanned by Coropuna and an additional 53065 people live in the downstream Camaná province (Instituto Nacional de Estadistica e Informatico (INEI), 2007) (Fig. 1). Although no known volcanic activity has occurred at Coropuna in modern times, the presence of Holocene-age lava flows flanking the ice cap is consistent with a volcanic system that is still active and where future magma recharge and/or eruptions could pose a hazard to local communities. Thus, it should be important that changes in Coropuna's ice extent are well known. Although nine previous studies have quantified the glacierized area of Coropuna (Ames and others, 1988; de Silva and Francis, 1990; Nunez-Juarez and ValenzuelaOrtiz, 2001; Racoviteanu and others, 2007; Forget and others, 2008; Peduzzi and others, 2010; Úbeda, 2011; Silverio and Jaquet, 2012; Veettil and others, 2016), these studies have produced inconsistent results (Fig. 2), leading to uncertainty in the fate of the ice cap as a meltwater source in the coming years to decades. 


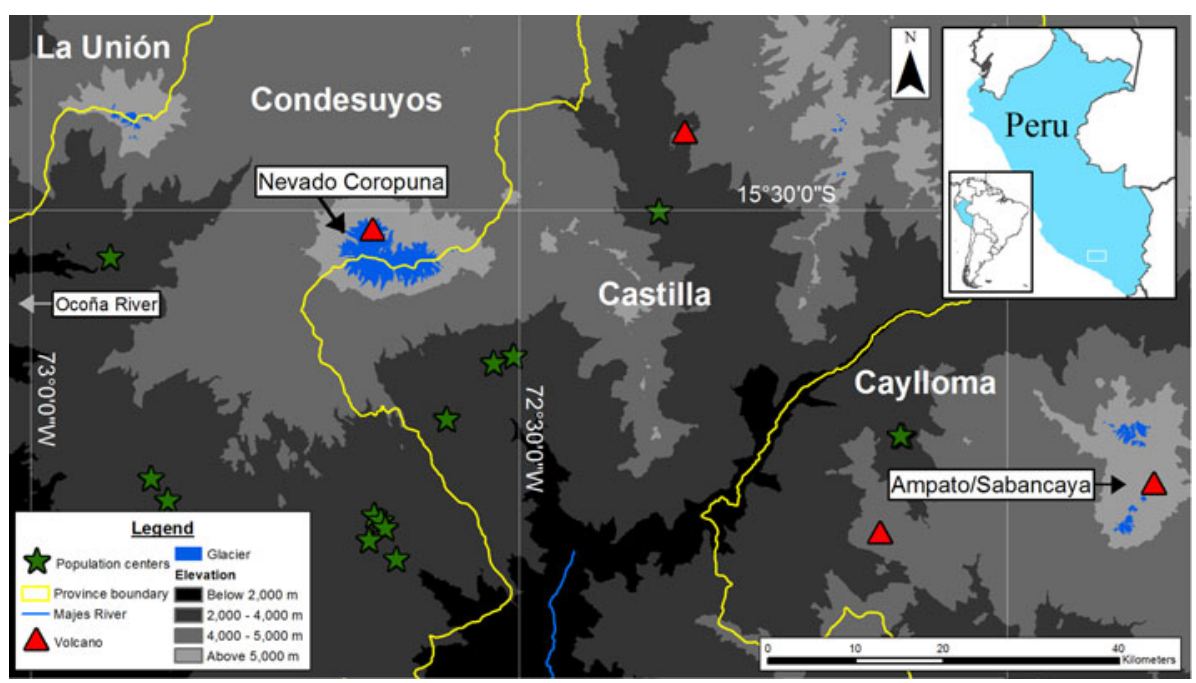

Fig. 1. Location map showing Nevado Coropuna Ice Cap in central Peru with respect to surrounding provincial boundaries. (Elevation data from SRTM through the USGS-EROS, NASA, and NGA. Country outline from DeLorme Publishing Company, Inc.)

To address the need for accurate glacier change time series for Nevado Coropuna, we have reconstructed a time series of its ice cap area using 259 Landsat 2, 4, 5 and 7 scenes from 1980 to 2014 . The goals of this study are (1) to understand the source of the discrepancies in previous ice area change estimates for Coropuna Ice Cap through a comparative analysis with a more comprehensive, better-constrained and longer dataset and (2) to discuss how the new results may be important for managing water resources.

\section{DATA AND METHODS}

Given the large areal extent, high elevation and difficult access of Coropuna Ice Cap, we focus on remote sensing observations to construct a multi-decadal time series of areal ice extent. Atmospherically corrected Landsat scenes from 1980 to 2014 were downloaded from the USGS Earth Explorer (https://earthexplorer.usgs.gov/). A total of one
Landsat 2, one Landsat 4, 158 Landsat 5 and 99 Landsat 7 scenes with cloud-free conditions over Coropuna were compiled. We constructed a time series of the Coropuna ice area using the Normalized Difference Snow Index (NDSI; Dozier, 1989; Hall and others, 1995) applied to the Landsat scenes in the ESRI ArcGIS model builder application. The NDSI is calculated as

$$
\mathrm{NDSI}=\left(R_{\mathrm{G}}-R_{\mathrm{SWIR}}\right) /\left(R_{\mathrm{G}}+R_{\mathrm{SWIR}}\right),
$$

where $R_{\mathrm{G}}$ and $R_{\mathrm{SWIR}}$ are the reflectivity of the green (band 2) and shortwave infrared (band 5) wavelengths, respectively, in Landsat 4, 5 and 7 images. We used the NDSI because it efficiently distinguishes snow and ice from the surrounding terrain (Hall and others, 1995; Albert, 2002), enabling construction of a more consistent and reproducible time series of Coropuna ice area change than possible using a manual approach (Paul and others, 2002, 2013; Paul and

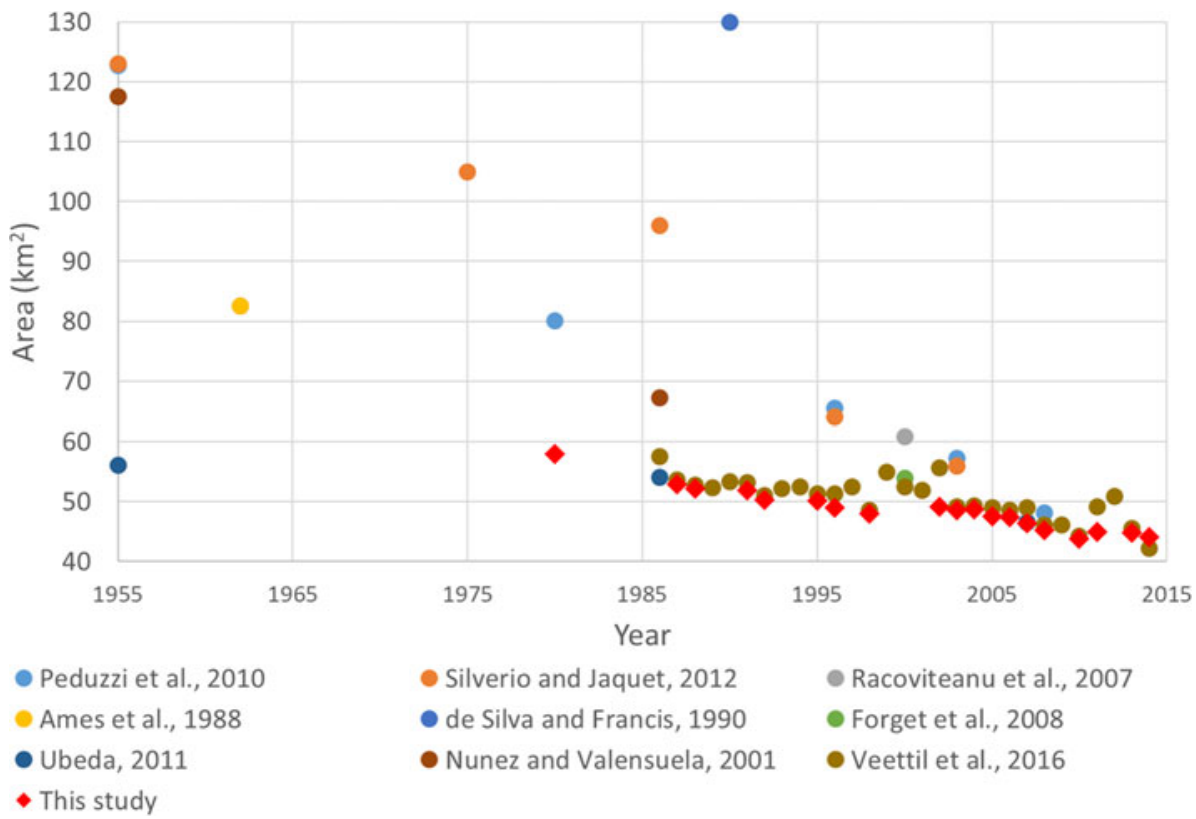

Fig. 2. Summary of estimates of glacierized area of Nevado Coropuna, Peru from nine previous studies. The error estimates of this study are shown in Figure 4. 
Andreassen, 2009). All 259 images in this study were manually inspected to ensure that clouds did not obscure the ice area and bias our extent estimates.

NDSI values can range from 0.25 to 1.0 (Hall and others, 1995). While a value of 0.5 is typical for glacier mapping (Albert, 2002), variations can exist between sites. To identify the most appropriate NDSI value for Coropuna, we computed the NDSI for all pixels in a 30 m-resolution Landsat 7 ETM scene from 26 November 2013. To crop the NDSI map to the Coropuna ice extent, we first manually mapped the Coropuna ice edge in a nearly contemporaneous highresolution (1.5 $\mathrm{m}$ panchromatic) SPOT image from 23 November 2013. The ice extent mask constructed using the SPOT image was eroded by $42.43 \mathrm{~m}$ (the diagonal length of one Landsat 7 pixel) to ensure that mixed pixels spanning the ice cap margin were excluded, then the mask was applied to the Landsat-derived NDSI map to extract NDSI values over just the ice area. Assuming that the spectral characteristics of the ice cap did not change substantially over the Landsat observation period, we used the minimum NDSI value of 0.5567 from the masked map to identify glacierized regions in all 259 Landsat images (i.e. NDSI snow\&ice $\geqslant$ 0.5567). The use of a Coropuna image-derived NDSI threshold increases the accuracy of our automated results relative to those obtained using an arbitrarily derived threshold because it accounts for the site-specific reflectance of the ice cap.

To construct a glacier extent time series, we first applied the NDSI threshold to all NDSI maps constructed using our Landsat 4, 5 and 7 time series (Fig. 3). From this dataset, we chose NDSI maps that contained the minimum snow and ice area for each given year to make 18 glacial areal extent measurements at Coropuna spanning 1987-2014 (Table 1, Fig. 3). We selected the NDSI maps with the minimum snow and ice area to quantify the Coropuna glacier area, rather than maps from an arbitrary date during the dry season, to minimize potential biases in extent estimates from non-glacierized snow-covered regions. Since shortwave infrared energy was not recorded by the Landsat 1-2 satellites, we could not apply the NDSI thresholding approach to images acquired prior to 1987 . To extend our time series before the 1987 launch of Landsat 4, we manually delineated the Coropuna ice extent in a cloud- and snow-free Landsat 2 image acquired on 12 December 1980. The final time series contains a total of 19 minimum annual snow and ice extent estimates for Coropuna from 1980 to 2014 (Fig. 3). Uncertainties in our extent time series are presented in the following section.

\section{ERROR ASSESSMENT OF MEASURED GLACIERIZED AREAS}

In glacier remote sensing, the four main sources of error are (1) positional errors, (2) processing errors, (3) conceptual errors (e.g. errors in defining glaciers such as transient snow cover) and (4) classification errors (Racoviteanu and others, 2009). Here we employed several methods to minimize all of these errors. To reduce positional errors, we manually inspected all acquired Landsat scenes to ensure accurate georeferencing based on ground control points geolocated by the USGS. To reduce processing errors, we used automatic methods of glacier classification, which have been found to be more robust than manual digitization for ice bodies large than $0.2 \mathrm{~km}^{2}$ (Paul and others, 2002; Paul and Andreassen, 2009). To reduce conceptual errors, we processed and manually inspected all 259 cloud-free observations in the Landsat archive to try to ensure that our glacier area measurements represent the annual snow minima. This leaves classification errors, described below, as the main source of uncertainty in our study.

To quantify uncertainty in our ice area classification measurements, we first compared the manually digitized Coropuna ice area in the SPOT image from 23 November 2013 and the NDSI-based area estimate from the nearly contemporaneous Landsat scene that was used to compute the NDSI threshold. Assuming that negligible area change

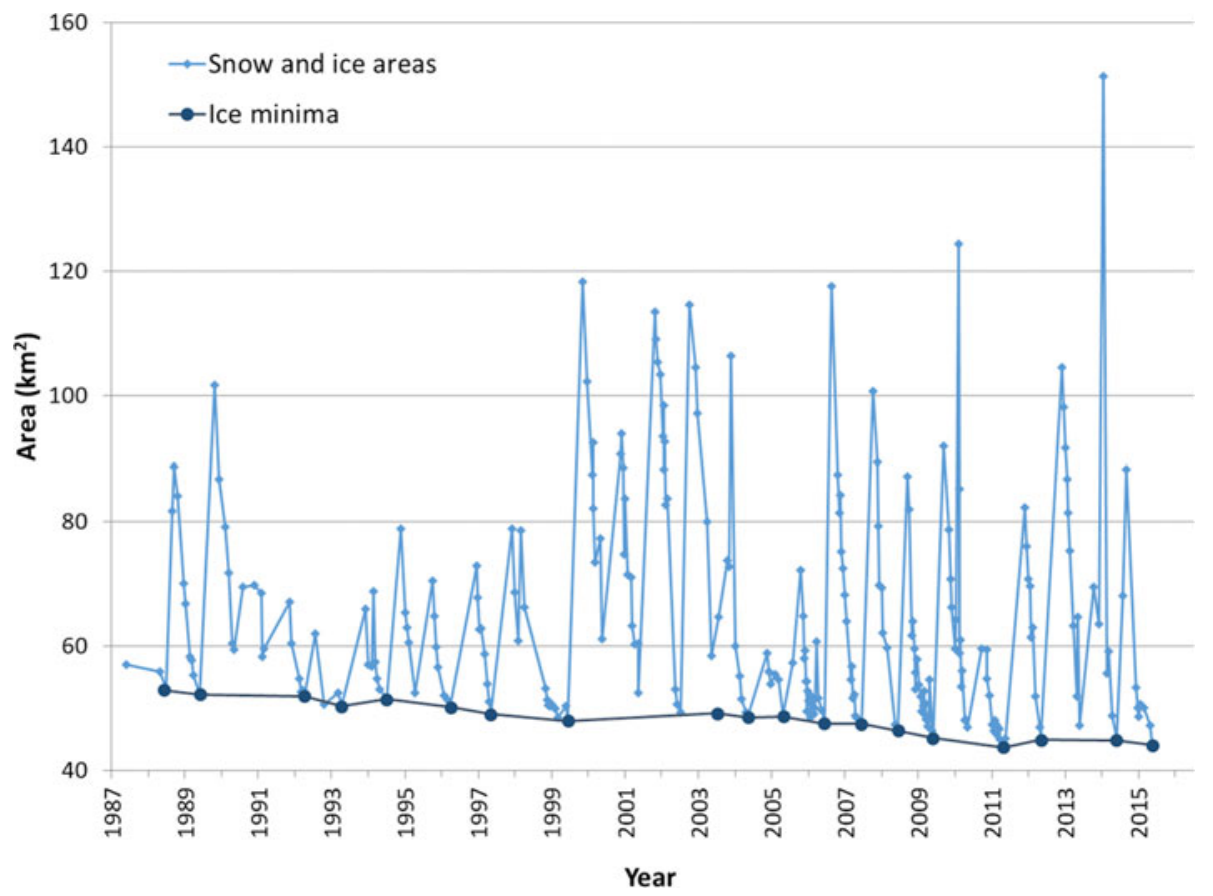

Fig. 3. Snow and ice areas from 259 Landsat scenes. The 19 ice minima used in this study are highlighted. 
Table 1. All 19 Landsat scene IDs, dates, areas and maximum uncertainty estimates used to measure the ice minima in this study

\begin{tabular}{llcc}
\hline Landsat scene ID & \multicolumn{1}{c}{ Date } & Area & $\begin{array}{c}\text { Maximum } \\
\text { uncertainty } \\
\mathrm{km}^{2}\end{array}$ \\
\hline LM20030711980347AAA03 & $12 / 12 / 1980$ & 58.0 & 7.0 \\
LT40040711987339XXX03 & $12 / 5 / 1987$ & 52.9 & 4.4 \\
LT50040711988334CUB00 & $11 / 29 / 1988$ & 52.2 & 4.4 \\
LT50040711991278CUB00 & $10 / 5 / 1991$ & 51.9 & 4.4 \\
LT50040711992281CUB00 & $10 / 7 / 1992$ & 50.3 & 4.4 \\
LT50040711995273CUB00 & $9 / 30 / 1995$ & 50.1 & 4.4 \\
LT50040711996308CUB00 & $11 / 4 / 1996$ & 49.0 & 4.4 \\
LT50040711998345CUB00 & $12 / 11 / 1998$ & 48.0 & 4.4 \\
LT50040712002004COA00 & $1 / 4 / 2002$ & 49.2 & 4.5 \\
LT50040712003311CUB00 & $11 / 7 / 2003$ & 48.6 & 4.4 \\
LT50040712004298CUB00 & $10 / 28 / 2004$ & 48.7 & 4.3 \\
LE70040712005340COA00 & $12 / 6 / 2005$ & 47.5 & 4.3 \\
LE70040712006343COA00 & $12 / 9 / 2006$ & 47.5 & 4.1 \\
LE70040712007346COA00 & $12 / 12 / 2007$ & 46.4 & 4.1 \\
LT50040712008325CUB00 & $11 / 20 / 2008$ & 45.2 & 4.2 \\
LT50040712010298CUB00 & $10 / 25 / 2010$ & 43.7 & 4.0 \\
LE70040712011309ASN00 & $11 / 5 / 2011$ & 44.9 & 4.1 \\
LE70040712013330CUB00 & $11 / 26 / 2013$ & 44.8 & 4.1 \\
LE70040712014317CUB00 & $11 / 13 / 2014$ & 44.1 & 3.9 \\
\hline
\end{tabular}

Maximum uncertainty estimates are derived using the mixed pixel approach. The Landsat 2 scene area is estimated with manual delineation, while all other area measurements utilize the NDSI. The spatial resolution of the Landsat 4, 5 and 7 images is $30 \mathrm{~m}$, while the Landsat 2 image is $60 \mathrm{~m}$ resolution.

occurred over the $3 \mathrm{~d}$ between image acquisitions, any difference in the area estimates can be attributed to the inability of the NDSI thresholding approach to accurately distinguish glacierized and non-glacierized pixels. A similar approach has been used to quantify the uncertainty in NDSI-derived glacier area estimates in previous studies (Paul, 2000, 2002; Paul and others, 2002). We obtained manually derived and NDSI-based area estimates of 44.95 and $44.85 \mathrm{~km}^{2}$, respectively, which is consistent with an uncertainty in our area estimates of $<1 \%$.
Since the SPOT image was used to define the area over which the NDSI threshold was computed, it is possible that this approach underestimates the true uncertainty in our area estimates. We took two additional approaches to estimate area uncertainties. The first assumed that pixel misclassification is the result of uncertainty in the NDSI threshold. We varied the value of the NDSI threshold by $5 \%$ to account for the quoted error in the digital number values of the Landsat satellites (NASA, 1998). We estimated that uncertainty in the NDSI threshold value leads to uncertainty in the total glacierized area of $0.58 \%$ on average (Fig. 4).

The second alternative approach assumed that pixel misclassification is restricted to the ice cap periphery, where uncertainty in the NDSI threshold will have the biggest impact on pixel classification due to the presence of mixed pixels (i.e. pixels that overlap the glacier and surrounding terrain or contain debris-laden ice). Assuming that all pixels in the perimeter were misclassified, we summed the number of perimeter pixels and multiplied by the pixel area $\left(900 \mathrm{~m}^{2}\right)$ to obtain an estimate of the maximum misclassified ice area. A similar approach was used by Rivera and others (2007) and Silverio and Jaquet (2005), among others, to quantify uncertainties in ice extent. A comparison of the estimated and maximum areas shows that the area uncertainty is $\sim 8.9 \%$ on average for Landsat 4,5 and 7 scenes (Table 1; Fig. 4) and $11 \%$ for the Landsat 2 scene.

We do not quantify potential error due to debris cover of Coropuna because we have observed little to no debris covered ice in both the satellite image archive and in the field. Assuming that debris covered ice will be optically distinct from neighboring bare ice and ice-free pixels, due to differences in spectral reflectance and/or surface texture, manual inspection of the $1.5 \mathrm{~m}$ resolution SPOT image reveals minimal debris covered ice. Inspection of an air photo taken on 23 December 2014 also suggests little to no debris cover (Fig. 5). It is also worth noting that in the absence of large temporal variations in debris cover, which

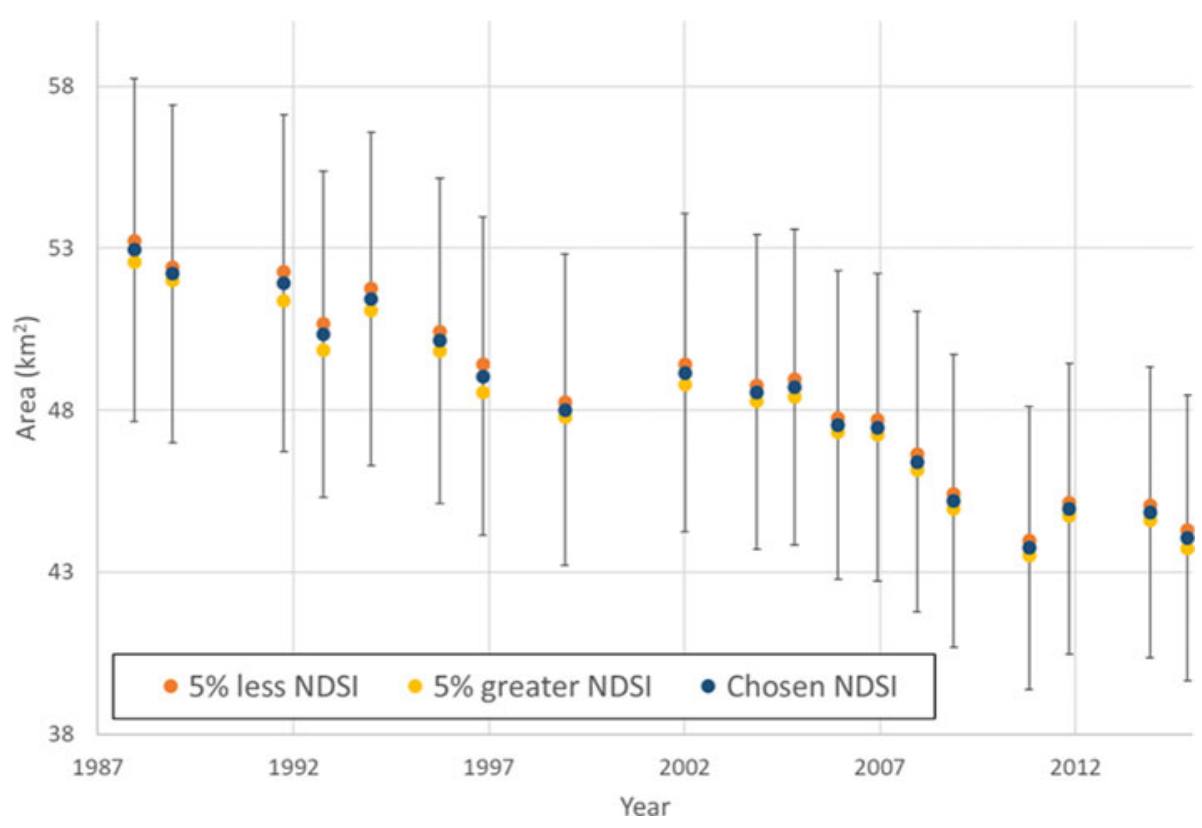

Fig. 4. Error assessment for Normalized Difference Snow Index (NDSI). The measured glacier area is shown (blue points) surrounded by the sensitivity analysis of the NDSI with a 5\% variation in values (yellow and orange points). The maximum estimated error due to the mixed pixel effect $(10 \%)$ is shown as vertical whiskers. 


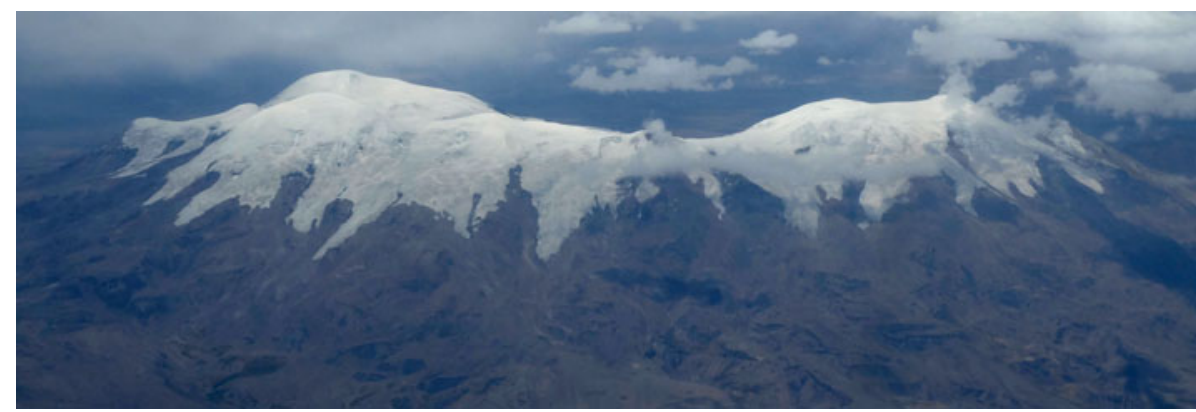

Fig. 5. Air photo of Coropuna. Image taken on 23 December 2014 showing little to no debris cover on the glaciers of Coropuna.

are unlikely given the absence of debris in the recent SPOT image and air photo, the presence of debris would lead to fairly systematic underestimation of the true ice area and would not influence the area change trend derived from our observations.

Based on the classification uncertainty estimates presented above, we conservatively assume an uncertainty of $10 \%$ for our glacierized area estimates. Paul and others (2013) found that measurements of the area of clean ice, such as the glaciers of Coropuna, typically have $\sim 5 \%$ uncertainty. We note that the true uncertainty in our area estimates is likely $<10 \%$ because it is highly improbable that all pixels around the ice cap margin are misclassified.

\section{RESULTS}

Our ice area measurements of Coropuna Ice Cap indicate that it is currently $\sim 11 \mathrm{~km}$ wide (from east to west) and $\sim 8.5 \mathrm{~km}$ long (from north to south) at the widest transects. To parse the ice cap into individual glaciers, we used the ASTER GDEM (available from https://earthexplorer.usgs. gov/) and the 1980 Coropuna ice outline from this study to identify individual glaciers of the ice cap and glacier centerlines following the method of Kienholz and others (2013, 2014). In 2014, the ice cap comprised 23 glaciers and three ice domes with a maximum elevation of $6414 \mathrm{~m}$. Glaciers on the north side extended to elevations as low as $5500 \mathrm{~m}$, while glaciers on the south side terminated at elevations as low as $5100 \mathrm{~m}$. The longest (5.2 km long) and shortest $(1.0 \mathrm{~km}$ long) glaciers coincidentally both retreated 400 $\mathrm{m}$ during the 35-year study period.

Our data on aerial extent indicate that Coropuna saw a total reduction in glacierized area of $24 \%$ from 1980 to 2014, from 58.0 to $44.1 \mathrm{~km}^{2}\left(13.9 \mathrm{~km}^{2}\right.$ lost). This equates to an average loss of $0.409 \mathrm{~km}^{2} \mathrm{a}^{-1}\left(0.71 \% \mathrm{a}^{-1}\right)$ (Fig. 6). Although the glacierized area of Coropuna decreased over nearly the entire study period, it appears to have increased slightly between 2010 and $2011\left(1.2 \mathrm{~km}^{2}\right.$; $\left.+2.7 \%\right)$. However, manual inspection of the glacierized area maps reveals that a portion of glacier 14 (Fig. 7) incorrectly appeared to detach from the ice cap in 2010, resulting in an underestimation of the ice area that year.

Our estimates show that Coropuna's ice area has exceeded the area of Quelccaya Ice Cap, which has long been recognized as the largest ice body in the tropics (Thompson and others, 2006; Salzmann and others, 2013), since at least the 1980s. The 2009 ice extent for Quelccaya was estimated at $42.8 \mathrm{~km}^{2}$ (Salzmann and others, 2013), while Coropuna had an area of $44.5 \pm 0.8 \mathrm{~km}^{2}$ in 2009 .
Spatio-temporal variability in glacier recession was assessed by dividing the ice cap into 23 hydrologic catchments and extracting area change estimates for each (Fig. 7). Our data indicate that although glacier retreat is ubiquitous, the magnitude and timing of retreat varies across the ice cap. Of the ice cap's 23 glaciers, 18 glaciers experienced their highest average rate of area loss from 1980 to 1992. However, if we exclude the 1980 data from our analysis because of the greater uncertainty associated with the manually delineated Landsat 2 scene, we find that 11 glaciers had the highest rates of retreat from 1987 to 1996 and another 11 glaciers had the highest rates of retreat during the most recent decade (2005-2014). While some glaciers appear to have occasionally increased in area during the 1980-2014 period (Fig. 7), these apparent increases are within the

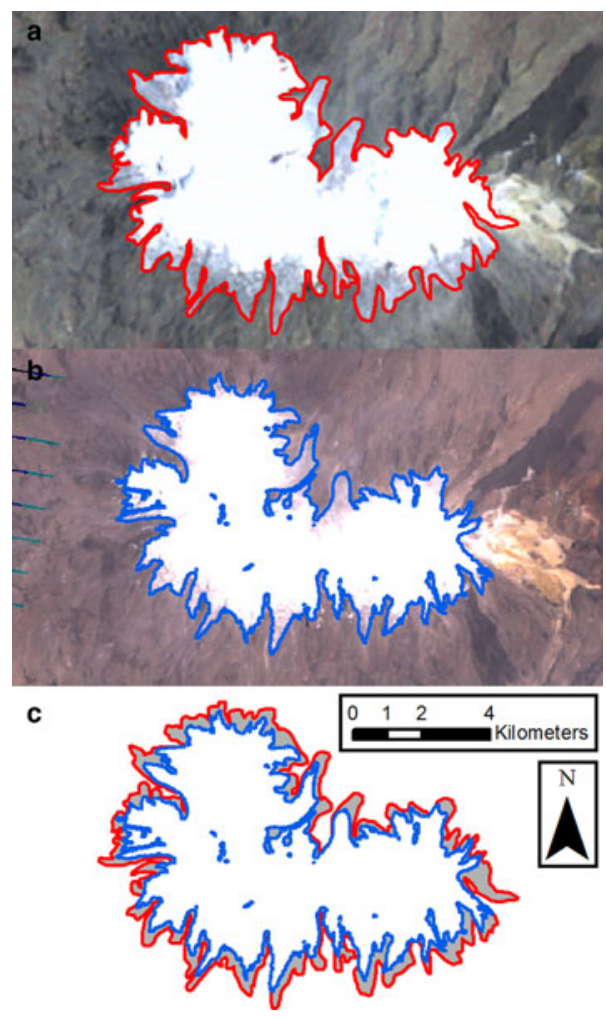

Fig. 6. Landsat scenes showing best estimates of ice-surface area change at Coropuna from 1980 to 2014. (a) Image from Landsat 2 taken on 12 December 1980 with an estimated area of $58.0 \mathrm{~km}^{2}$. (b) Image from Landsat 7 taken on 13 November 2014 with an estimated area of $44.1 \mathrm{~km}^{2}$. (c) Schematic map highlighting total net change in ice areal extent (24.0\%) from 1980 to 2014 . 

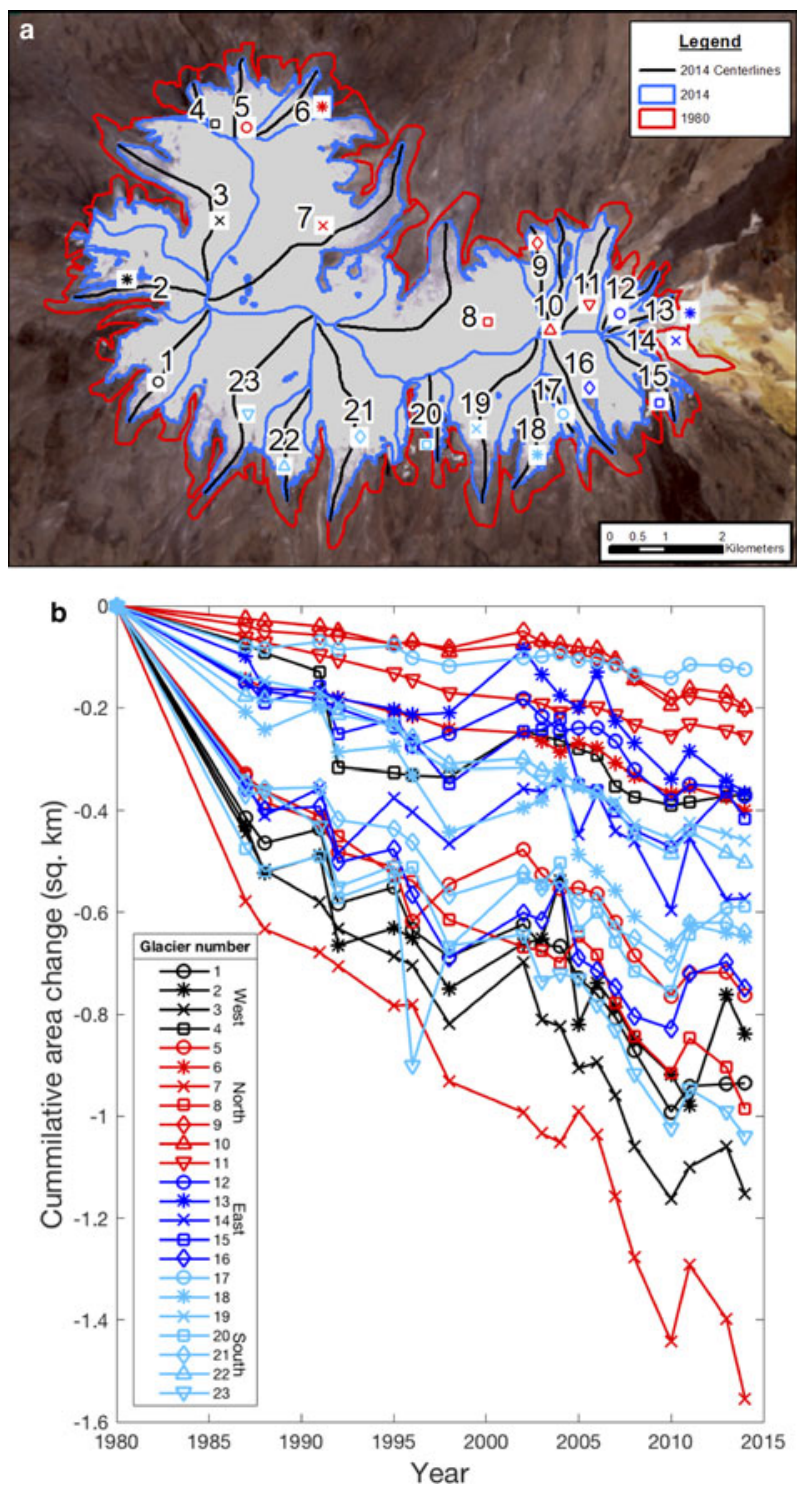

Fig. 7. Individual glacier change on Coropuna Ice Cap. (a) Individual glaciers are shown for 1980 (red) and 2014 (blue) with 2014 centerlines (black) and symbols used in Figure 8b. (b) The absolute area change of the 23 individual glaciers of Coropuna is shown by year. Glaciers on the west side are shown in black, north side in red, east side in dark blue, south side in light blue. Each glacier is also given a unique symbol.

estimated uncertainty for each glacier, which varies with the length of the glacier margin from $4.3 \%$ (glacier 8 ) to $30.1 \%$ (glacier 14).

While every glacier of Coropuna Ice Cap has retreated at least $4.7 \%$ in length during the 35-year study period (Fig. 8), the magnitude of retreat varies widely across the ice cap. In order to assess whether topography exerts a strong control over the observed, variable glacier retreat, we compared variations in area and length change over time to differences in the aspect, slope and elevation. Our data show that shorter, steeper, lower and south facing glaciers are retreating the most rapidly. But correlations are weak between the percent decrease in length and the initial centerline length $\left(R^{2}=0.11\right)$ and mean slope $\left(R^{2}=0.31\right)$ as well as between the magnitude of retreat and mean elevation $\left(R^{2}=0.12\right.$; Fig. 8). All other correlations were found to have an $R^{2}$ value $<0.11$

\section{DISCUSSION}

\subsection{Area change rates}

Although nine studies have previously attempted to quantify the glacierized area and rates of ice loss for Coropuna (Ames and others, 1988; de Silva and Francis, 1990; Nunez-Juarez and Valenzuela-Ortiz, 2001; Racoviteanu and others, 2007; Forget and others, 2008; Peduzzi and others, 2010; Úbeda, 2011; Silverio and Jaquet, 2012; Veettil and others, 2016), the results of these studies are inconsistent with each other (Fig. 2) and with what has been found at other tropical glaciers. Inspection of our NDSI-based snow and ice extent estimates for the observation dates included in these previous studies (Fig. 2) reveals that de Silva and Francis (1990), Ames and others (1988), Nunez-Juarez and ValenzuelaOrtiz (2001), Racoviteanu and others (2007), Forget and others (2008), Peduzzi and others (2010) and Veettil and others (2016) overestimated at least one glacierized area measurement in their time series because of the presence of seasonal snow. Silverio and Jaquet (2012) are the most frequently cited source on Coropuna's glaciers by government agencies, yet our snow and ice covered area time series shows that they overestimate rates of glacier recession by using images blanketed by snow in early years and images with less snow in years closer to the present. For example, comparison of an image from 1 August 1985 used by Silverio and Jaquet (2012) to an image from 5 December 1987 shows a $45 \%$ decrease in the estimation of glacier area (Fig. 9). This is physically untenable. Our analysis shows that the image from 5 December 1987 more accurately represents glacierized area because the glacial margins are not obscured by snow. úbeda (2011) provides two new area estimates from a 1986 orthophotograph and a 2007 ASTER scene that are consistent with our findings and support our inference that the Silverio and Jaquet (2012) results overestimate ice area in the 1980s, and thus rates of ice cap recession.

In the most recent of the previous Coropuna studies, Veettil and others (2016) measured annual snowlines and glaciated areas. They reported large interannual variations in glacierized area, as much as $9 \%$, that seem highly unlikely. These unrealistic variations could be due to their use of different NDSI thresholds for each satellite image, or to the inclusion of satellite images with snow cover. We were unable to verify the inclusion of snow-covered scenes in Veettil and others (2016) because they did not report Landsat scene identifiers, but find that their estimates of ice extent range from $4.2 \%$ greater to $13.4 \%$ less than our measurements. While they suggested that the snow minima occur between May and September, our work demonstrates that the majority of ice-minimum measurements occurred in November and December (seven each) over the 34-year (1980-2014) satellite image record. In fact, May observations are annual snow cover area maxima with peak snow cover occurring on 4 May $\pm 49 \mathrm{~d}$ ( 1 std dev.). We find that the snow covered area minimum is 19 November $\pm 28 \mathrm{~d}$ ( 1 std dev.). Therefore, it is highly likely that the large variability in Coropuna Ice Cap extent reported by Veettil and others (2016) is not due to fluctuations in the glacier area but rather the presence of off-ice or ice-marginal snow and a changing NDSI value.

Based on the comparison of our area estimates with those of previous studies, and inspection of the images utilized by these studies, we conclude that the retreat rate of Coropuna 

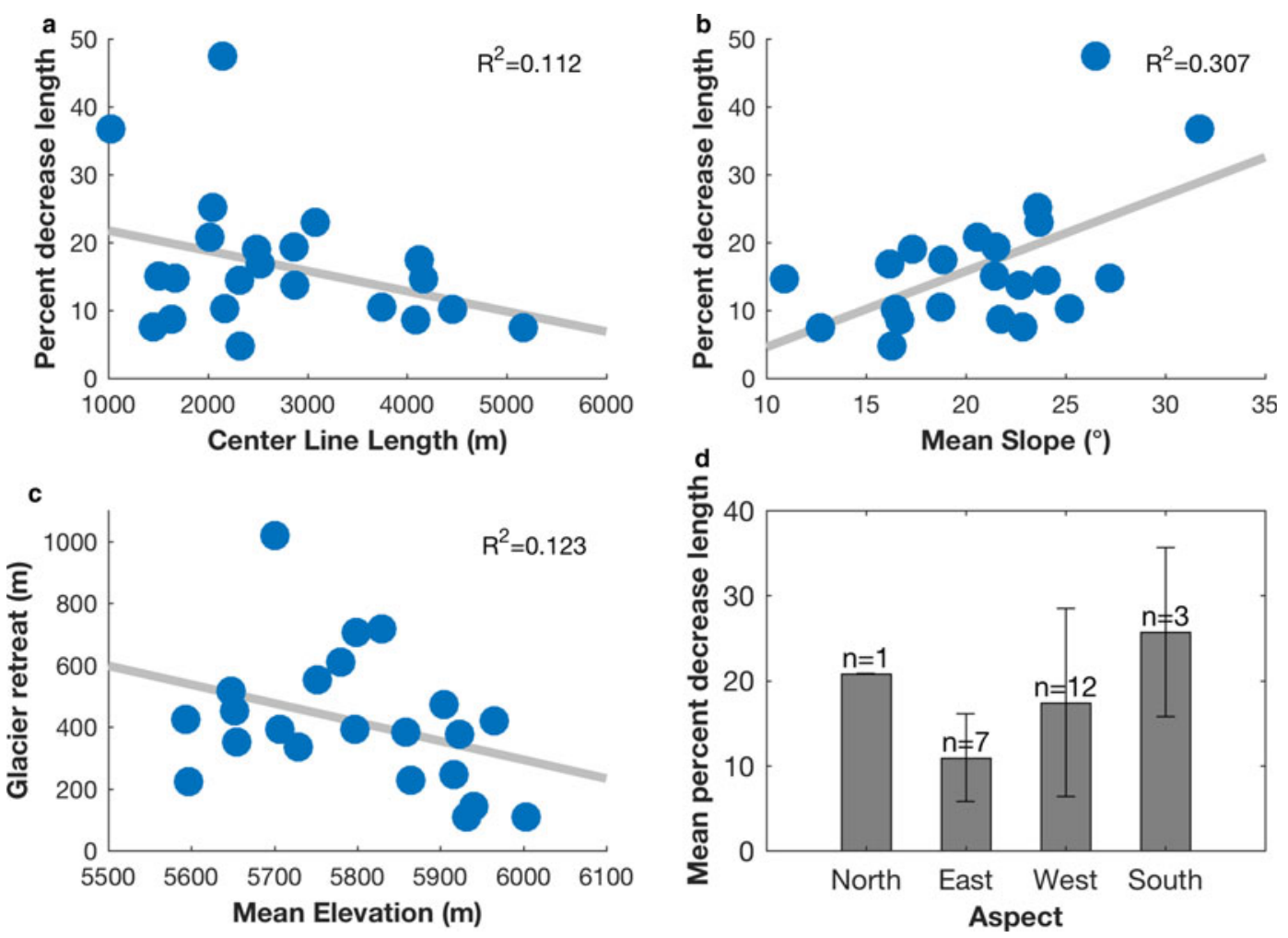

Fig. 8. Retreat characteristics of 22 glaciers. Blue points in each subplot represent individual glaciers. (a) Center line length is plotted against percent decrease in length with a gray line of best fit $\left(R^{2}=0.112\right.$ ). (b) Mean slope is plotted against percent decrease in length with a gray line of best fit $\left(R^{2}=0.307\right)$. (c) Mean glacier elevation is plotted against absolute length change with a gray line of best fit $\left(R^{2}=0.112\right)$. (d) Glaciers are grouped into bins ranging $\pm 45^{\circ}$ from cardinal direction and plotted against the mean percent decrease in length of the group of glaciers. Whiskers show $1 \mathrm{std}$ dev. One glacier has become disconnected from the eastern flank of the ice cap since 1980, resulting in $0.19 \mathrm{~km}^{2}$ of stranded ice in 2014, which is excluded from these plots.

Ice Cap has been previously overestimated because of the presence of transient snow cover, leading to anomalously rapid and variable recession rates for the ice cap relative to other high-altitude tropical glaciers. The ability to rapidly analyze the entire Landsat archive allowed us to document times of the year when snow cover was minimal and avoid snow cover errors that likely negatively impacted earlier studies. Our analysis yields rates of Coropuna Ice Cap recession that now align more closely with what we would expect for Peruvian glaciers (Fig. 10). Although the termini of some tropical glaciers are receding at rates of over $2 \% \mathrm{a}^{-1}$, including Puncak Jaya (New Guinea; Klein and Kincaid, 2006) and Colombian mountain ice bodies (Ceballos and others, 2006), most Peruvian glaciers have documented retreat rates of $\sim 0.5-1.5 \% \mathrm{a}^{-1}$ (Fig. 10). Our area change time series suggests that Coropuna Ice Cap is receding at a rate of $0.71 \%$ $\mathrm{a}^{-1}$ on average, which is similar to the Cordillera Blanca (Peru; Fig. 10; Vuille and others, 2008; Baraer and others, 2012). However, we find variable rates of retreat between the 23 glaciers from 0.44 to $2.41 \% \mathrm{a}^{-1}$ during the study period. We hypothesize that the similar recession rates for Coropuna and the glaciers of the Cordillera Blanca are due to similarities in climate in the two regions. Though sparse weather records make it impossible to thoroughly test this hypothesis, the similar elevations of glaciers, prevailing wind direction and proximity to moisture sources for the regions (Kaser, 1999; Vuille and others, 2008) make it likely that the glaciers in the Cordillera Blanca and Coropuna experience similar climate.

While few studies have reported similar individual tropical glacier measurements as we do in Figure 8, other studies generally agree with our findings. Salzman and others (2013) and Rabatel and others (2013) both found that glaciers in the tropical Andes have higher rates of retreat at lower elevations. Additionally, Salzman and others (2013) reported that longer glaciers tend to have lower normalized rates of retreat. Our observations generally support these relationships, albeit weakly. We hypothesize that these relationships are weak because Coropuna hosts glaciers with varying characteristics and retreat rates.

The 23 glaciers that together form Coropuna Ice Cap have experienced vastly different retreat rates through time (Figs 7 , 8). Although no spatial groupings of retreat rates among the 23 glaciers are obvious (Fig. 7), our results show that during the late 1990s and early 2000s almost all of the individual glaciers experienced lower rates of retreat than the previous and succeeding periods. This suggests that the ice cap as a whole experienced less melting during the late 1990s and early 2000s; however, we are unable to determine if temperatures were lower during this period due to the lack of weather station data. This spatio-temporal variability in glacier recession emphasizes the need for more detailed studies of the climate on Coropuna in order to better understand their disparate responses to climate change.

\section{IMPLICATIONS FOR FUTURE WATER SUPPLY}

A report from the Peru Environmental Ministry (Ministerio del Ambiente del Perú, 2010), which has been cited by the United States Agency for International Development (USAID), indicates that the Peruvian government is currently preparing for the ice cap of Coropuna to be a non-contributor 


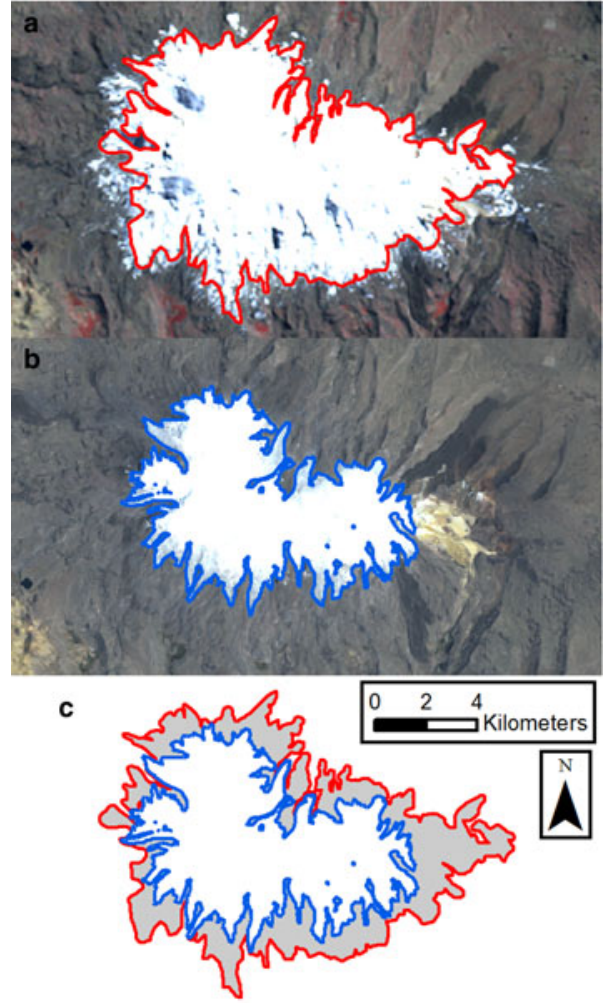

Fig. 9. Comparison of estimated ice area as a function of month. (a) Silverio and Jaquet (2012) estimated a glacierized area of $96.4 \pm 15$ $\mathrm{km}^{2}$ on 1 August 1985. (b) Estimated glacierized area of $52.9 \mathrm{~km}^{2}$ on 5 December 1987 (this study). (c) Composite image shows apparent change in ice extent of $45 \%$ with December 1987 dashed outline and August 1985 solid outline. to water supply by 2025 (Ministerio del Ambiente del Perú, 2010; Stark and others, 2012). If Coropuna meltwater production plummets, it will cause significant economic stress for populations living in this arid region, especially during dry seasons when glacier meltwater is the dominant source of fresh water (Úbeda, 2011; Silverio and Jaquet, 2012). The implementation of adaptation measures for a decrease in glacial meltwater runoff from Coropuna would exacerbate stress on the developing Peruvian economy in this region (Lasage and others, 2015). Assuming that Coropuna Ice Cap continues to retreat at the same rate of $0.409 \mathrm{~km}^{2} \mathrm{a}^{-1}$ as it has during the last 30 years, glaciers on Coropuna could potentially persist until $\sim 2120$. These results suggest that adaptation measures can likely be implemented over a longer timeframe, which may mitigate economic stress.

To derive first-order estimates of the recent contribution of Coropuna meltwater to the local water budget, we use a glaciological approach (Frenierre and Mark, 2014) and assume an average ice thickness of $80.8 \mathrm{~m}$ (Peduzzi and others, 2010). Previous estimates of ice loss at Coropuna ( 1.4 $\mathrm{km}^{2} \mathrm{a}^{-1}$ ) translate into an average output of $1010000 \mathrm{~L}$ of water per person per year for an estimated local population of 100 000 people. Using this same method, we estimate that the actual water output is at most $297000 \mathrm{~L}$ per person per year, given an area change rate of $0.409 \mathrm{~km}^{2} \mathrm{a}^{-1}$, not accounting for the high rates of sublimation that occur in the arid tropics (Wagnon and others, 1999). Rates of mass loss are likely to vary tremendously between catchments due to measured differences in the rate of glacier recession (Figs 7, 8) and ice thickness (Peduzzi and others, 2010). The impacts of glacier mass loss on local hydrologic systems and downstream populations should also vary

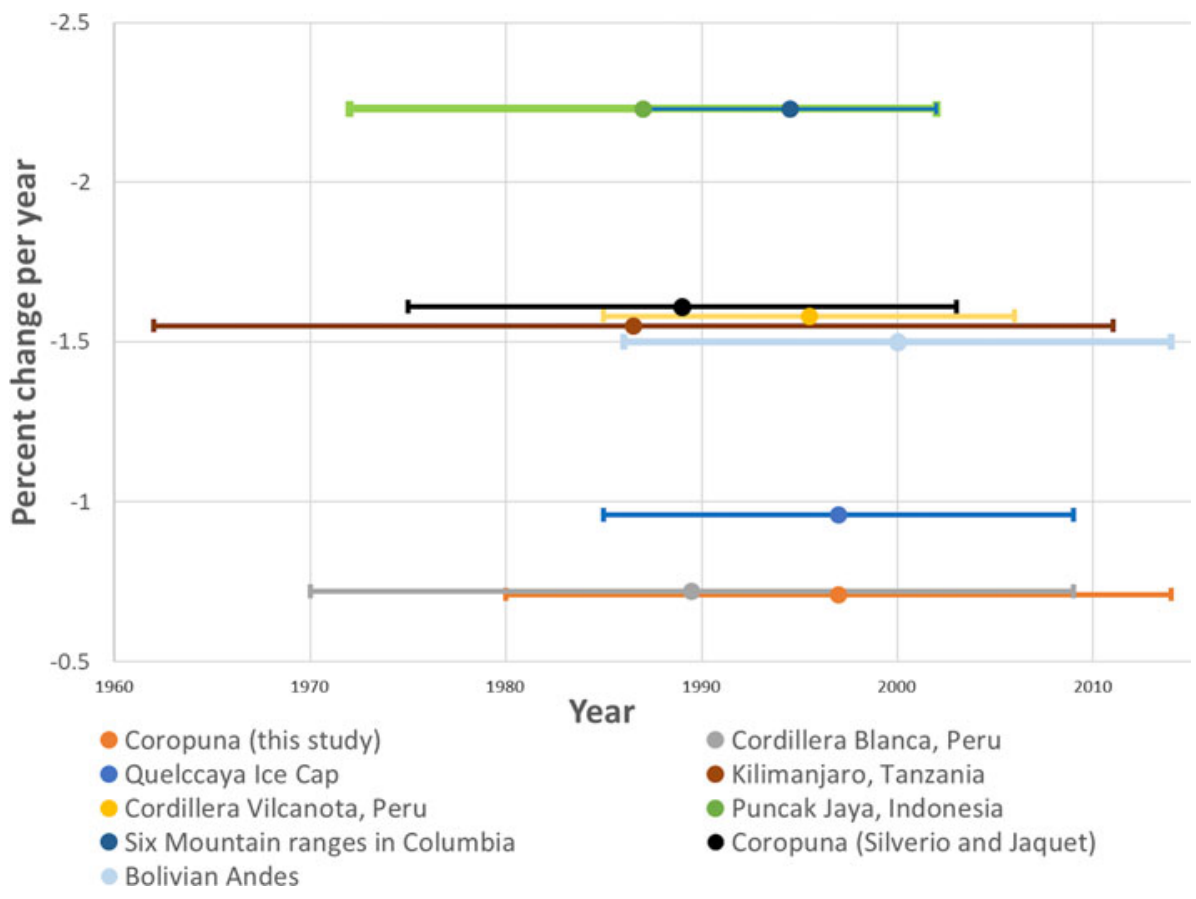

Fig. 10. Normalized shrinking rates of global tropical glaciers. Rates shown for Killimanjaro (Cullen and others, 2013), Puncak Jaya (Klein and Kincaid, 2006), Colombian mountain ice bodies (Ceballos and others, 2006), Cordillera Blanca (Baraer and others, 2012), Cordillera Vilcanota (Salzmann and others, 2013), Quelccaya (Salzmann and others, 2013), Bolivian Andes (Cook and others, 2016) and Coropuna (this study and Silverio and Jaquet, 2012). 
widely with differences in the relative contribution of glacier meltwater to stream discharge and water use practices. In the Cordillera Blanca, glaciers have been estimated to provide up to $30 \%$ of annual runoff within some watersheds (Mark and Seltzer, 2003). The loss of glaciers from these areas could reduce the discharge of glacially fed streams by as much as $30 \%$ during the dry season, limiting their importance as water resources (Baraer and others, 2012). In order to understand the impacts of the observed glacier recession on water resources and to prepare for changes in water availability in the future, we recommend that our regional meltwater runoff estimate be validated and parsed into individual catchments using in situ observations. This highlights the need for more current and precise volume change studies of the Coropuna ice cap. While Peduzzi and others (2010) and Racoviteanu and others (2007) have both previously attempted to estimate Coropuna volume change, their uncertainties are large. Future measurements of volume change will be immensely helpful to decision makers in the region.

\section{CONCLUSIONS}

From an analysis of 259 Landsat scenes, we found that Coropuna Ice Cap is shrinking at a rate of $0.409 \mathrm{~km}^{2} \mathrm{a}^{-1}$. From 1980 to 2014, the ice cap has decreased from 58.0 to $44.1 \mathrm{~km}^{2}$, a $24 \%$ decrease in area. Our average area change rate is in good agreement with recession rates for other high altitude tropical ice bodies, such as the Cordillera Blanca, and suggests that Coropuna's ice cap will persist for decades longer than previous estimates. We attribute the faster and more variable rates of retreat in previous studies to the use of satellite images containing transient snow cover. This underscores the need to select images that capture the annual ice minima when using automated mapping techniques to estimate glacier area change. Although we find the average area change rate is lower than previous estimates, we note that the magnitude of retreat varies widely across Coropuna's 23 glaciers with no clear spatial patterns. Thus, it should be imperative that glacier area and meltwater runoff changes are monitored using in situ observations at the scale of individual or combined glacier catchments in order to devise more accurate predictions of glacier recession and impacts on local water resources in the coming decades.

\subsection{Data availability}

All Landsat and ASTER GDEM data used in this study can be obtained from the USGS Earth Explorer. ASTER GDEM is a product of METI and NASA. All products of this study have been archived with the GLIMS Glacier Database.

\section{ACKNOWLEDGEMENTS}

Kochtitzky and Edwards acknowledge Dan and Betty Churchill, the Dickinson College Research and Development Committee, and Provost Neil Weissman for funding the 2015 field season in Peru. Kochtitzky and Edwards thank the staff of the Observatorio Vulcanológico de INGEMMET for ground support. Kochtitzky and Edwards thank Lonny Thompson for useful discussions about work at Coropuna. Kochtitzky thanks James Ciarrocca at Dickinson College for his GIS advice and guidance and Christian Kienholz for his help in making the glacier outlines and centerlines. We thank Ronald Concha with the GA51 Cryosphere and Climate Change project of INGEMMET for the SPOT image. We would like to thank Simon Cook, Christian Huggel, Graham Cogley, Thomas Mölg and four anonymous reviewers for their comments on previous versions of this manuscript. We also thank the Dickinson College Research and Development Committee for financially supporting the publication of this article. Kochtitzky acknowledges the National Science Foundation Graduate Research Fellowship Program under grant No. DGE-1144205 for supporting the later stages of this project.

\section{REFERENCES}

Albert TH (2002) Evaluation of remote sensing techniques for icearea classification applied to the tropical Quelccaya ice cap, Peru. Polar Geogr., 26(3;3), 210-226.

Ames A, Evangelista P, Valverde A and Zúñiga J (1988) Inventario de Glaciares del Perú. Inventario de Glaciares del Perú part 1. Consejo Nacional de Ciencia y Tecnologia, Huaraz, Peru.

Baraer M and 8 others (2012) Glacier recession and water resources in Peru's Cordillera Blanca. J. Glaciol., 58(207), 134-150 (doi: 10.3189/2012JoG11J186)

Björnsson H (1988) Hydrology of ice caps in volcanic regions. Societas Scientarium Islandica, University of Iceland, Reykjavík.

Ceballos JL and 6 others (2006) Fast shrinkage of tropical glaciers in Colombia. Ann. Glaciol., 43, 194-201 (doi: 10.3189/ 172756406781812429)

Cook SJ, Kougkoulos I, Edwards LA, Dortch J and Hoffmann D (2016) Glacier change and glacial lake outburst flood risk in the Bolivian Andes. Cryosphere, 10(5), 2399. (doi: 10.5194/tc2016-140)

Cullen NJ and 5 others (2013) A century of ice retreat on Kilimanjaro; the mapping reloaded. Cryosphere [Online], 7 (2;2), 419-431 (doi: 10.5194/tc-7-419-2013)

Delgado-Granados $\mathrm{H}$ and 7 others (2015) Chapter 17. Hazards at Ice-Clad Volcanoes: phenomena, processes, and examples from Mexico, Columbia, Ecuador, and Chile. In Haeberli W and Whiteman C, eds. Snow and Ice-related hazards, risks and disasters. Elsevier, Amsterdam, 607

de Silva SL and Francis PW (1990) Potentially active volcanoes of Peru; observations using Landsat thematic mapper and space shuttle imagery. Bull. Volcanol., 52(4;4), 286-301

Dozier J (1989) Spectral signature of alpine snow cover from the Landsat Thematic Mapper. Remote Sens. Environ., 28, 9-22 (doi: 10.1016/0034-4257(89)90101-6)

Forget ME, Thouret JC, Kuentz A and Fontugne M (2008) Héritages glaciaires, périglaciaires et évolution récente : le cas du Nevado Coropuna (Andes centrales, sud du Pérou) (French). Géomorphologie (Paris), (2), 113-132

Frenierre JL and Mark BG (2014) A review of methods for estimating the contribution of glacial meltwater to total watershed discharge. Prog. Phys. Geogr., 38(2), 173-200 (doi: 10.1177/ 0309133313516161)

Hall DK, Riggs GA and Salomonson V V (1995) Development of methods for mapping global snow cover using moderate resolution imaging spectroradiometer data. Remote Sens. Environ., 54(2), 127-140 (doi: 10.1016/0034-4257(95)00137-P)

Instituto Nacional de Estadistica e Informatico (INEI) (2007) Censos Nacionales 2007 XI Poblaciíon y Vi de Vivienda. http://censos. inei.gob.pe.

Kargel JS (2014) Scientific and public perceptions about the importance of fluctuations in glaciers and ice sheets. In Kargel JS ed. Global land Ice measurements from space. Springer-Verlag, Berlin, xi-xxvii (doi: 10.1007/978-3-540-7)

Kaser G (1999) A review of the modern fluctuations of tropical glaciers. Glob. Planet. Change, 22(1-4-4), 93-103. 
Kienholz C, Hock R and Arendt AA (2013) Instruments and methods a new semi-automatic approach for dividing glacier complexes into individual glaciers. J. Glaciol., 59(217), 925-937 (doi: 10.3189/2013JoG12J138)

Kienholz C, Rich JL, Arendt AA and Hock R (2014) A new method for deriving glacier centerlines applied to glaciers in Alaska and northwest Canada. Cryosphere, 8(2), 503-519 (doi: 10.5194/tc8-503-2014)

Klein AG and Kincaid JL (2006) Retreat of glaciers on Puncak Jaya, Irian Jaya, determined from 2000 and 2002 IKONOS satellite images. J. Glaciol., 52(176;176), 65-79 (doi: 10.3189/ $172756506781828818)$

Lasage R and 5 others (2015) A stepwise, participatory approach to design and implement community based adaptation to drought in the Peruvian Andes. Sustainability, 7(2), 1742-1773 (doi: 10.3390/su7021742)

Magrin G and 7 others (2014) Central and South America. In: Climate Change 2014: Impacts, Adaptation, and Vulnerability. Part B: Regional Aspects. Contribution of Working Group II to the Fifth Assessment Report of the Intergovernmental Panel on Climate Change [Barros, V.R., C.B. Fiel]. (doi: 10.2134/ jeq2008.0015br)

Major JJ and Newhall CG (1989) Snow and ice perturbation during historical volcanic eruptions and the formation of lahars and floods; a global review. Bull. Volcanol., 52(1;1), 1-27.

Mark BG and Seltzer GO (2003) Tropical glacier meltwater contribution to stream discharge: a case study in the Cordillera Blanca, Peru. J. Glaciol., 49(165), 271-281. (doi: 10.3189/ 172756503781830746)

Ministerio del Ambiente del Perú (2010) El Perú y el Cambio Climático Segunda Comunicación Nacional del Perú: a la Convención Marco de las Naciones Unidas sobre Cambio Climático 2010: Impresiones \& Ediciones Aguilar S.A.C.

National Aeronautics and Space Administration (1998) Landsat 7 science data users handbook. NASA, Greenbelt, ML

Nunez-Juarez S and Valenzuela-Ortiz G (2001) Mapa Preliminar de Amenaza Volcanica Potencial del Nevado Coropuna; Estudios de Riesgos Volcanicos en el Sur del Peru. Bol. - Inst. Geol. Mineria, Ser. C Geodin. Ing. Geol., 25, 103.

Paul $F$ (2000) Evaluation of different methods for glacier mapping using Landsat TM. EARSeL eProc., 1(1;1), 239-245 (doi: 10.1080/10106040008542173)

Paul F (2002) Changes in glacier area in Tyrol, Austria, between 1969 and 1992 derived from Landsat 5 thematic mapper and Austrian Glacier Inventory data. Int. J. Remote Sens., 23(4;4), 787-799 (doi: 10.1080/01431160110070708)

Paul F and Andreassen LM (2009) A new glacier inventory for the Svartisen region, Norway, from Landsat ETM + data: challenges and change assessment. J. Glaciol., 55(192), 607-618. (doi: 10.3189/002214309789471003)

Paul F, Huggel C, Kääb A, Kellenberger T and Maisch M (2002) Comparison of TM-derived glacier areas with higher resolution data sets. In EARSeL Workshop on remote sensing of land ice and snow, Bern, Vol. 11, No. 13.3.

Paul F and 19 others (2013) On the accuracy of glacier outlines derived from remote-sensing data. Ann. Glaciol., 54(63), 171182 (doi: 10.3189/2013AoG63A296)

Peduzzi P, Herold C and Silverio W (2010) Assessing high altitude glacier thickness, volume and area changes using field, GIS and remote sensing techniques: the case of Nevado Coropuna (Peru). Cryosphere 4(3) (doi: 10.5194/tc-4-313-2010)

Pierson TC (1995) Flow characteristics of large eruption-triggered debris flows at snow-clad volcanoes; constraints for debris-flow models. J. Volcanol. Geotherm. Res., 66(1-4-4), 283-294.

Rabatel A, and 10 others (2013) Current state of glaciers in the tropical Andes: a multi-century perspective on glacier evolution and climate change. Cryosphere, 7(1), 81-102 (doi: 10.5194/tc-7-812013)

Racoviteanu AE, Manley WF, Arnaud Y and Williams MW (2007) Evaluating digital elevation models for glaciologic applications; an example from Nevado Coropuna, Peruvian Andes. Glob. Planet. Change, 59(1-4-4), 110-125 (doi: 10.1016/j. gloplacha.2006.11.036)

Racoviteanu AE, Paul F, Raup B, Khalsa SJS and Armstrong R (2009) Challenges and recommendations in mapping of glacier parameters from space: results of the 2008 Global Land Ice Measurements from Space (GLIMS) workshop, Boulder, Colorado, USA. Ann. Glaciol., 50(53), 53-69 (doi: 10.3189/ 172756410790595804)

Rivera A, Benham T, Casassa G, Bamber JL and Dowdeswell JA (2007) Ice elevation and areal changes of glaciers from the Northern Patagonia Icefield, Chile. Glob. Planet. Change, 59(14-4), 126-137 (doi: 10.1016/j.gloplacha.2006.11.037)

Salzmann N and 6 others (2013) Glacier changes and climate trends derived from multiple sources in the data scarce Cordillera Vilcanota region, southern Peruvian Andes. Cryosphere [Online], 7(1;1), 103-118 (doi: 10.5194/tc-7-103-2013)

Silverio W and Jaquet J-M (2005) Glacial cover mapping (1987-1996) of the Cordillera Blanca (Peru) using satellite imagery. Remote Sens. Environ., 95(3;3), 342-350 (doi: 10.1016/j.rse.2004.12.012)

Silverio W and Jaquet J-M (2012) Multi-temporal and multi-source cartography of the glacial cover of Nevado Coropuna (Arequipa, Peru) between 1955 and 2003. Int. J. Remote Sens., 33(18), 5876-5888 (doi: 10.1080/01431161.2012.676742)

Smellie J and Edwards B (2016) Glaciovolcanism on Earth and Mars. Cambridge University Press, Cambridge, 493 p. (doi: 10.1017/ CBO9781139764384)

Stark J, Guillén S and Brady C (2012) Follow the Water: Emerging Issues of Climate Change and Conflict in Peru. United States Agency for International Development, Washington DC

Thompson LG and 8 others (2006) Abrupt tropical climate change; past and present. Proc. Natl. Acad. Sci. USA, 93(28;28), 10536-10543 (doi: 10.1073/pnas.0603900103)

úbeda J (2011) El Impacto del Cambio Climático en los Glaciares del Complejo Volcánico Nevado Coropuna, (Cordillera Occidental de los Andes Centrales). Universidad Complutense de Madrid, Madrid.

Veettil BK, Bremer UF, de Souza SF, Maier ÉLB and Simões JC (2016) Variations in annual snowline and area of an ice-covered stratovolcano in the Cordillera Ampato, Peru, using remote sensing data (1986-2014). Geocarto Int., 31(5), 544-556 (doi: 10.1080/10106049.2015.1059902)

Vuille $M$ and 6 others (2008) Climate change and tropical Andean glaciers; past, present and future. Earth-Sci. Rev., 89(3-4-4), 7996 (doi: 10.1016/j.earscirev.2008.04.002)

Wagnon P, Ribstein P, Kaser G and Berton P (1999) Energy balance and runoff seasonality of a Bolivian glacier. Glob. Planet. Change, 22(1-4), 49-58 (doi: 10.1016/S0921-8181(99)00025-9) 